\title{
$N$-Acetyl Indole Linked to a Fused Triazolo/Thiadiazole Scaffold: Synthesis, Single Crystal X-Ray Structure, and Molecular Insight
}

\author{
Ahmed T. A. Boraei ${ }^{1}{ }^{*}$, Saied M. Soliman ${ }^{2}\left(\mathbb{D}\right.$, Sammer Yousuf ${ }^{3}$, Memoona Bibi ${ }^{3}$ and \\ Assem Barakat $4, *$ (D) \\ 1 Chemistry Department, Faculty of Science, Suez Canal University, Ismailia 41522, Egypt \\ 2 Department of Chemistry, Faculty of Science, Alexandria University, P.O. Box 426, Ibrahimia, \\ Alexandria 21321, Egypt; saied1soliman@yahoo.com \\ 3 H.E.J. Research Institute of Chemistry, International Center for Chemical and Biological Sciences, \\ University of Karachi, Karachi 75270, Pakistan; dr.sammer.yousuf@gmail.com (S.Y.); \\ monauok702@gmail.com (M.B.) \\ 4 Department of Chemistry, College of Science, King Saud University, P.O. Box 2455, \\ Riyadh 11451, Saudi Arabia \\ * Correspondence: ahmed_tawfeek83@yahoo.com (A.T.A.B.); ambarakat@ksu.edu.sa (A.B.); \\ Tel.: +966-11467-5901 (A.B.); Fax: +966-11467-5992 (A.B.)
}

Received: 17 June 2020; Accepted: 9 July 2020; Published: 10 July 2020

check for updates

\begin{abstract}
The designed target compound of $N$-acetyl indole linked to a fused triazolo/thiadiazole scaffold was synthesized via the reaction of 4-amino-5-(1H-indol-2-yl)-1,2,4-triazol-3(2H)-thione as the starting material with acetic anhydride under reflux conditions for $6 \mathrm{~h}$, resulting in an excellent and pure chemical yield. The structural features of the designed compound were confirmed using spectroscopic tools including single crystal $\mathrm{X}$-ray diffraction analysis along with ${ }^{1} \mathrm{H}-\mathrm{NMR},{ }^{13} \mathrm{C}-\mathrm{NMR}, 2 \mathrm{D}-\mathrm{NMR}$, and high resolution mass spectrometry. Using Hirshfeld analysis, we determined the molecular packing depends on strong interactions $(\mathrm{O} \cdots \mathrm{H}$ and $\mathrm{N} \cdots \mathrm{H})$ along with weak interactions $(\mathrm{S} \cdots \mathrm{H}, \mathrm{C} \cdots \mathrm{H}$ and $\mathrm{H} \cdots \mathrm{H})$.

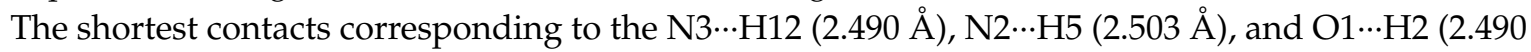
$\AA$ ) interactions were confirmed based on the Hirshfeld analysis. The calculated dipole moment was 6.6557 Debye. The atomic charge distribution, molecular electrostatic potential map, and reactivity descriptors are also discussed. The computed NMR spectra of the requisite compound correlated well with the results obtained experimentally. The UV-Vis electronic spectra of the requisite compound were simulated using the TD-DFT method and compared with the experimental data. The different $\sigma \rightarrow \sigma^{*}, \pi \rightarrow \pi^{*}, \mathrm{n} \rightarrow \sigma^{*}$, and $\mathrm{n} \rightarrow \pi^{*}$ donor-acceptor interactions and their interaction energies stabilized the studied system to $9.84,20.65,29.33$, and $45.82 \mathrm{kcal} / \mathrm{mol}$, respectively.
\end{abstract}

Keywords: indole; 4-amino-1,2,4-triazole-3-thiones; DFT; Hirshfeld analysis

\section{Introduction}

Heterocyclic compounds are of great importance in our daily life. Almost all basic biochemical processes of living cells are mediated by biomolecules that contain these ring systems, such as enzymes, coenzymes, heme, hormones, vitamins, chlorophyll, amino acids, carbohydrates (in cyclic forms), and nucleic acids. Therefore, many synthetic heterocyclic scaffolds are designed to mimic the structure of natural metabolites, peptides, or proteins in 3D space in order to interact with the biological targets. Additionally, heterocyclic frameworks, notably those containing nitrogen and/or oxygen atoms, are considered as valuable sources for new synthetic drug candidates of high functional specialization and are targeted by drug discovery and development research programs to fight diseases. They are 
extensively used in agriculture as fungicides, herbicides, and insecticides. N/S-heterocycles have many industrial applications including as electron transport materials for phosphorescent organic light-emitting diodes (ETMs for PHOLEDs), as corrosion inhibitors for mild steel, and as light stabilizers of plastic materials. Moreover, many commercially significant dyestuffs contain mainly nitrogen-based heterocycles [1].

Specifically, the substituted 4-amino-1,2,4-triazole-3-thiones scaffold exhibits a wide range of pharmacological patterns such as antimicrobial [2], antimalarial [3], anti-cancer [4], antiproliferative [5], and anticonvulsant agents [6]; it also inhibits enzymes such as ureases [7], acetylcholinesterase (AChE) [8], dizinc metallo- $\beta$-lactamase [9], and protein tyrosine phosphatase 1B [10].

Indeed, the indole nucleus is a fused bicyclic compound derived by fusion of the benzene ring with the pyrrole ring. Pharmacologically, indole is a privileged core structure embedded in a very interesting group of polycyclic alkaloids that exhibit a wide spectrum of important biological activities including anti-human immunodeficiency virus (anti-HIV) [11], anti-inflammatory [12], anti-malarial [13], anti-microbial [14], anti-vascular [15], anti-convulsant [16], and $\alpha$-glucosidase inhibiting [17] properties; ischemia/reperfusion injury [18]; and anti-proliferative activity for EGFR and PARP-1 potential inhibitors [19-21].

In continuation of our research program [22-26] to design a new scaffold that may be useful for material science, we have reported here a new motif-attributed indole synthon linked with a fused triazolo/thiadiazole scaffold at position 2 of the indole nucleus. The structural features of the designed compound were assigned based on single crystal X-ray diffraction techniques and a set of spectroscopic and spectrophotometric techniques. The molecular insight of the target molecule was also explored.

\section{Materials and Methods}

\subsection{General}

“Melting points were measured via a melting-point apparatus (SMP10) in open capillaries and are uncorrected. The progress of the reaction was observed by thin layer chromatography (TLC) using $\mathrm{MeOH} / \mathrm{CH}_{2} \mathrm{Cl}_{2}$ 1:9 as the eluent. Detection was achieved by UV light. Nuclear magnetic resonance $\left({ }^{1} \mathrm{H}-\mathrm{NMR},{ }^{13} \mathrm{C}-\mathrm{NMR}\right.$, and 2D-NMR) spectra were determined in DMSO- $d_{6}$ and were recorded on Bruker AC $400 \mathrm{MHz}$ spectrometers in the presence of tetramethylsilane as an internal standard. Chemical shifts are described in $\delta$ (ppm) and coupling constants are given in Hz. HREI mass spectra as recorded with a Finnigan MAT 95XP instrument. X-ray crystallographic analysis was collected by using a Bruker SMART APEX II D8 Venture diffractometer at Karachi University. $\lambda$ max was measured using a T90 + UV/VIS spectrometer."

\subsection{Synthesis of 1-(2-(6-methyl-[1,2,4]triazolo[3,4-b][1,3,4]thiadiazol-3-yl)-1H-indol-1-yl)ethan-1-one}

First, 4-Amino-5-(1H-indol-2-yl)-1,2,4-triazol-3 $(2 H)$-thione (1.0 mmol) was heated under reflux in acetic anhydride $(10 \mathrm{~mL})$ for $6 \mathrm{~h}$, after cooling to RT then cooled water was added. Then, the solid product was obtained by filtration, kept to dry, and finally recrystallized from $\mathrm{EtOH}$.

Yield: $72 \%$ as colorless needle crystals (EtOH). M.p. $208-210{ }^{\circ} \mathrm{C} ;{ }^{1} \mathrm{H}-\mathrm{NMR}\left(400 \mathrm{MHz}, \mathrm{DMSO}-d_{6}\right) \delta$ $2.52\left(\mathrm{~s}, 3 \mathrm{H}, \mathrm{CH}_{3}\right), 2.73\left(\mathrm{~s}, 3 \mathrm{H}, \mathrm{CH}_{3}\right), 7.34-7.39\left(\mathrm{~m}, 2 \mathrm{H}, \mathrm{H}-3_{\text {indole, }} \mathrm{H}-5_{\text {indole }}\right), 7.45-7.51$ (m, $\left.1 \mathrm{H}, \mathrm{H}-6_{\text {indole }}\right)$, $7.78\left(\mathrm{~d}, 1 \mathrm{H}, J_{4,5}=7.7 \mathrm{~Hz}, \mathrm{H}-4_{\text {indole }}\right), 8.10\left(\mathrm{~d}, 1 \mathrm{H}, J_{6,7}=8.4 \mathrm{~Hz}, \mathrm{H}-7_{\text {indole }}\right) ;{ }^{13} \mathrm{C}-\mathrm{NMR}(100 \mathrm{MHz}$, DMSO- $\left.d_{6}\right) \delta 17.95\left(\mathrm{CH}_{3}\right), 26.35\left(\mathrm{COCH}_{3}\right), 114.94(\mathrm{C}-3$ indole $), 115.16\left(\mathrm{C}-7_{\text {indole }}\right), 121.99\left(\mathrm{C}-4_{\text {indole }}\right)$,

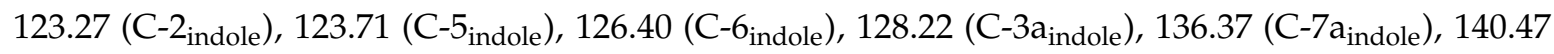
(C-3 triazolo-thiadiazole $), 154.76$ (C-7 $\left.\mathrm{a}_{\text {triazolo-thiadizole }}\right), 167.38$ (C-6 triazolo-thiadizole $\left._{\text {) }}\right), 170.03$ (C=O); HRMS (EI) calculated for $\mathrm{C}_{14} \mathrm{H}_{11} \mathrm{~N}_{5} \mathrm{OS}(\mathrm{M}+)$ : 297.0684. Found: 297.0664 .

\subsection{Single-Crystal X-Ray Diffraction Analysis}

$X$-ray diffraction data of the target molecule were collected on a Bruker D8 Venture Diffractometer with the aid of $\mathrm{Cu} \mathrm{K} \alpha(\lambda=1.54178 \AA)$ radiation source and CMOS Photon 100 detector 100 (2). 
Data integration and reduction were carried out with an APEX 3 software package (version 1, Bruker Scientific Instruments, Billerica, MA, USA) [27] followed by use of the SHELXL programs to solve and refine the final structure [28] (Table 1). Geometrical calculations and intermolecular interaction studies were performed on PLATON and Mercury 3.10.1, respectively [29,30]. An ORTEP diagram (Figure 1) described the three-dimensional representation of the title compound. Methyl hydrogen atoms were located from difference Fourier maps or from geometrical considerations and then were refined at idealized positions riding on the carbon atoms with isotropic displacement parameters $\mathrm{U}_{\text {iso }}(\mathrm{H})=1.2 \mathrm{U}_{\text {eq }}(\mathrm{C})$ or $1.5 \mathrm{U}_{\text {eq }}$ (methyl) and $\mathrm{C}-\mathrm{H}$ 0.95-0.98 $\AA$. The Crystal Explorer 17.5 program was employed to explore the topology analyses of the requisite compound [31].

Table 1. Experimental crystal dataset of the target molecule.

\begin{tabular}{|c|c|}
\hline \multicolumn{2}{|c|}{ Compound Description } \\
\hline Chemical formula & $\mathrm{C}_{14} \mathrm{H}_{11} \mathrm{~N}_{5} \mathrm{OS}$ \\
\hline Formula weight & 297.34 \\
\hline Temperature & 104(2) K \\
\hline Wavelength & $1.54184 \mathrm{~A}$ \\
\hline Crystal system & Monoclinic \\
\hline Space group & $\mathrm{Cc}$ \\
\hline Unit cell dimensions & $\begin{array}{c}\mathrm{a}=10.9381(19) \AA \\
\mathrm{b}=11.2508(19) \AA \\
\mathrm{c}=11.289(2) \AA \\
\beta=101.404(13)^{\circ}\end{array}$ \\
\hline Volume & $1361.8(4) \mathrm{A}^{3}$ \\
\hline $\mathrm{Z}$ & 4 \\
\hline Calculated density & $1.450 \mathrm{Mg} / \mathrm{m}^{3}$ \\
\hline Absorption coefficient & $2.175 \mathrm{~mm}^{-1}$ \\
\hline $\mathrm{F}(000)$ & 616 \\
\hline Crystal size & $0.40 \times 0.14 \times 0.13$ \\
\hline Theta range for data collection & 7.425 to $68.432^{\circ}$ \\
\hline Limiting indices & $\begin{array}{c}-13<=\mathrm{h}<=13 \\
-13<=\mathrm{k}<=13 \\
-13<=1<=12\end{array}$ \\
\hline Reflections collected & 15863 \\
\hline Completeness to theta $=67.684$ & $98.5 \%$ \\
\hline Refinement method & Full-matrix least-squares on $\mathrm{F}^{2}$ \\
\hline Independent reflections & 2410 \\
\hline Data/restraints/parameters & $2410 / 2 / 193$ \\
\hline Goodness-of-fit on $\mathrm{F}^{2}$ & 1.019 \\
\hline Flack parameter & $0.067(5)$ \\
\hline $\mathrm{R}$ indices (all data) & $\mathrm{R} 1=0.0254, \mathrm{wR} 2=0.0697$ \\
\hline Final R indices (I > 2sigma (I)) & $\mathrm{R} 1=0.0256, \mathrm{wR} 2=0.0701$ \\
\hline Largest diff. peak and hole & 0.119 and $-0.152 \mathrm{eA}^{-3}$ \\
\hline CCDC & 2010068 \\
\hline
\end{tabular}




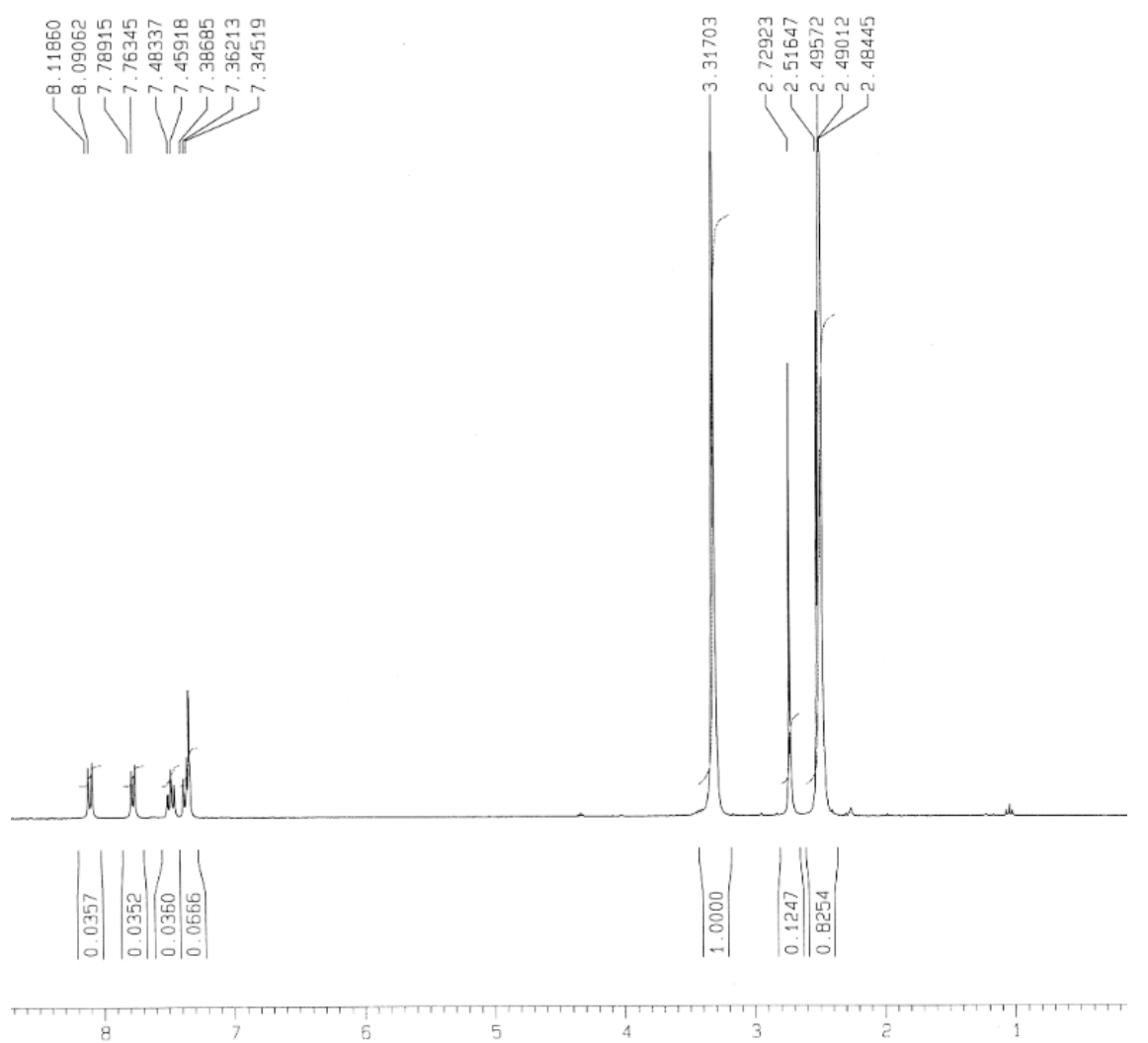

(a)

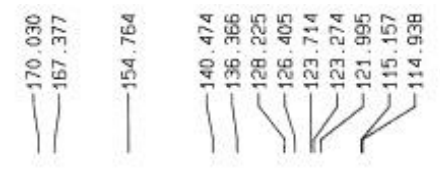

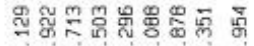

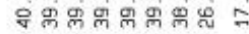
L(N)

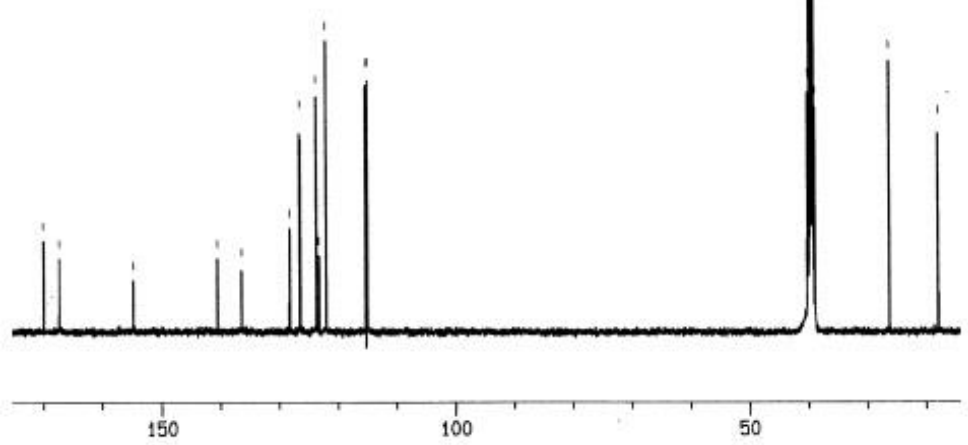

(b)

Figure 1. (a) ${ }^{1} \mathrm{H}-\mathrm{NMR}$ and (b) ${ }^{13} \mathrm{C}-\mathrm{NMR}$ spectrum analysis 


\subsection{Computational Methods}

"All DFT calculations were performed using the Gaussian 09 software package [32] and utilizing the B3LYP/6-31G $(\mathrm{d}, \mathrm{p})$ method. Natural bond orbital analyses were performed using the NBO 3.1 program as implemented in the Gaussian 09W package [33]. The self-consistent reaction filed (SCRF) method $[34,35]$ was used to model the solvent (DMSO) effects when calculating the optimized geometries in solution. Then, the NMR chemical shifts for the protons and carbons were computed using the GIAO method in the same solvent (DMSO) [36]. Similarly, the structure was optimized in a solution of compound using ethanol as the solvent, then the optimized molecular structure was used to calculate the electronic spectra using the time-dependent density functional theory (TD-DFT).

\section{Results and Discussion}

\subsection{Synthesis of the Target Compound}

The target het 1-(2-(6-methyl-[1,2,4]triazolo[3,4-b][1,3,4]thiadiazol-3-yl)-1H-indol-1-yl)ethan-1-one was synthesized from the reaction of 4-amino-5-(1H-indol-2-yl)-1,2,4-triazol-3(2H)-thione with $10 \mathrm{~mL}$ acetic anhydride for $6 \mathrm{~h}$, resulting in acetylation of the indole nitrogen in addition to a new thiadiazole ring closure (Scheme 1).

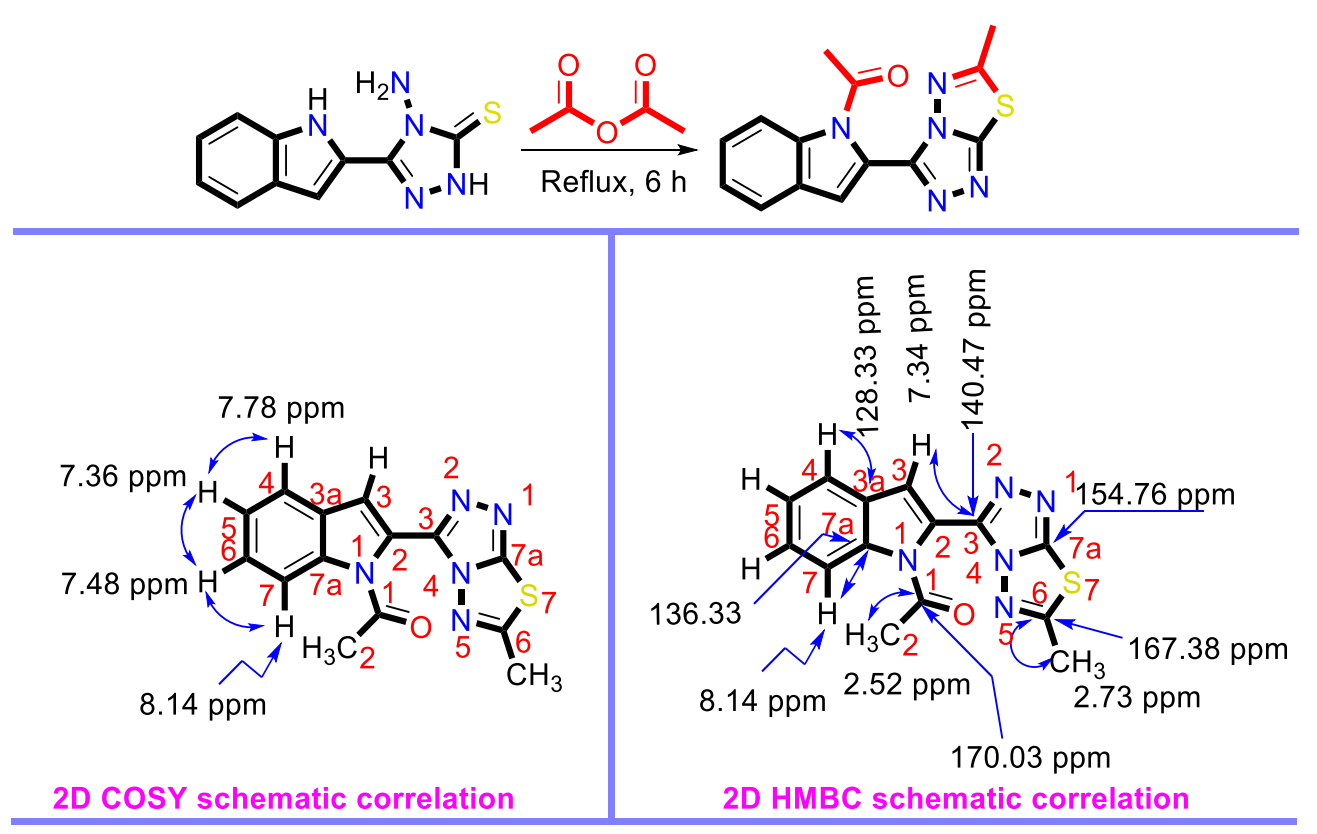

Scheme 1. Synthesis of the target compound and 2D-COSY and 2D-HMBC schematic correlations.

The structure of the target compound was elucidated based on ${ }^{1} \mathrm{H}-\mathrm{NMR}$, which showed five aromatic protons at $\delta 7.34,7.36,7.48,7.78$, and $8.10 \mathrm{ppm}$ for five indole protons in addition to two methyl group signals at $\delta 2.52$ and $2.73 \mathrm{ppm} .{ }^{13} \mathrm{C}-\mathrm{NMR}$ displayed five $\mathrm{CH}$ aromatic signals at $\delta$ $114.94,115.16,121.99,123.71$, and $126.40 \mathrm{ppm}$ corresponding to five indole $\mathrm{CH}$ carbons. The indole quaternary carbons appeared at $\delta 123.27,128.22$, and $136.37 \mathrm{ppm}$. The triazole-thiadiazole quaternary carbons appeared at $\delta 140.47,154.76$, and $167.38 \mathrm{ppm}$. Additionally, the carbonyl carbon appeared at $170.03 \mathrm{ppm}$. Finally, the two methyl carbons appeared at $\delta 17.95$ and $26.35 \mathrm{ppm}$.

${ }^{1} \mathrm{H}-{ }^{1} \mathrm{H}$ correlation spectroscopy (COSY) helped in assigning the positions of the indole vicinal protons, which demonstrated ${ }^{3} J_{\mathrm{H}, \mathrm{H}}$ coupling correlations between the protons at $\delta 7.78$ and $7.36 \mathrm{ppm}$, the latter also correlated with the proton at $\delta 7.48 \mathrm{ppm}$, and this proton also coupled with the proton at $8.14 \mathrm{ppm}$. The 2D-HMQC NMR was used for assigning the correlation and position of each $\mathrm{CH}$ and $\mathrm{CH}_{3}$. 
To assign the position of quaternary carbons, 2D-HMBC NMR spectroscopy was used, which displayed ${ }^{2} \mathrm{~J}_{\mathrm{C}, \mathrm{H}}$ coupling correlations between the methyl protons at $\delta 2.52 \mathrm{ppm}$ and the carbon at $170.03 \mathrm{ppm}$. The methyl protons at $\delta 2.73 \mathrm{ppm}$ displayed a ${ }^{2} J_{\mathrm{C}, \mathrm{H}}$ correlation with the carbon at $\delta 167.38 \mathrm{ppm}$. The proton at $\delta 7.34 \mathrm{ppm}$ displayed a ${ }^{3} J_{\mathrm{C}, \mathrm{H}}$ coupling correlation with carbon at $\delta$ $140.47 \mathrm{ppm}$. The indole proton at $\delta 7.78 \mathrm{ppm}$ demonstrated a ${ }^{2} J_{\mathrm{C}, \mathrm{H}}$ coupling correlation with carbon at $\delta 128.33 \mathrm{ppm}$. The proton at $8.14 \mathrm{ppm}$ showed a ${ }^{2} J_{\mathrm{C}, \mathrm{H}}$ coupling correlation with carbon at $\delta 136.37 \mathrm{ppm}$ (Figures 1 and 2).

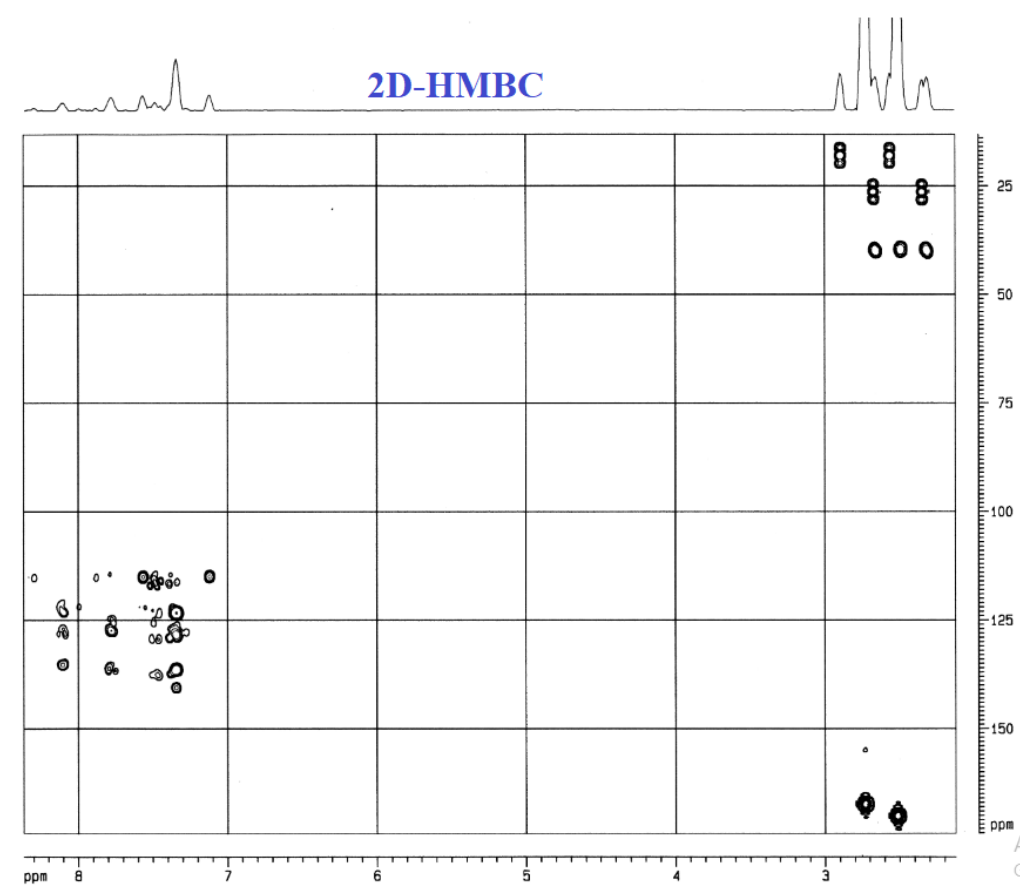

(a)

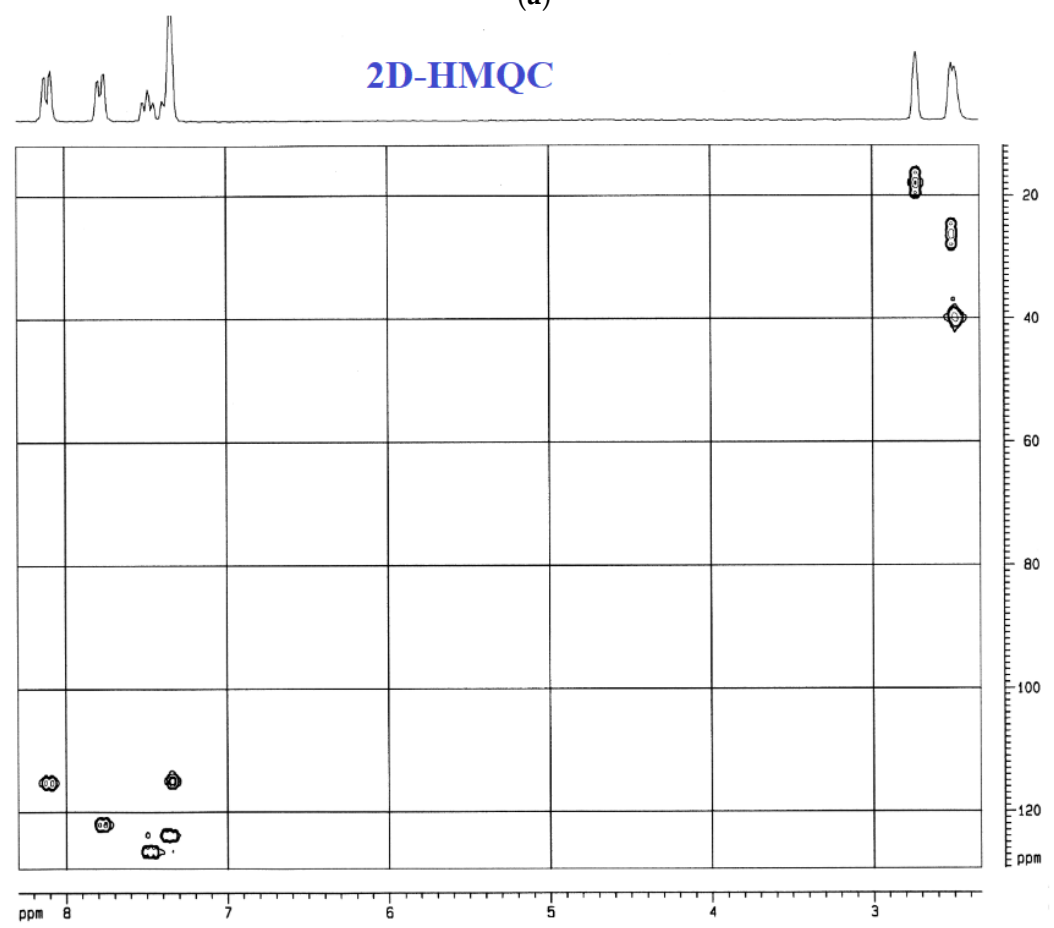

(b)

Figure 2. Cont. 


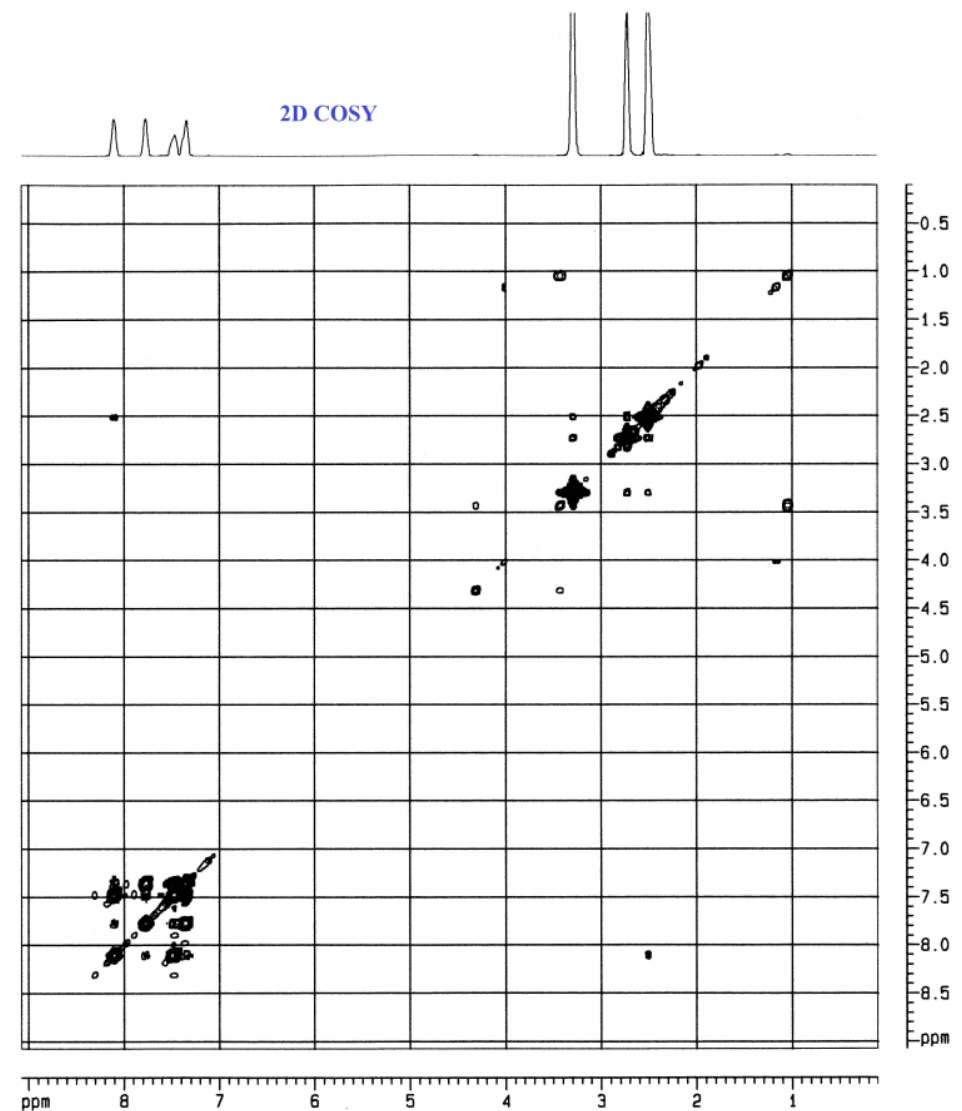

(c)

Figure 2. (a) 2D-HMBC, (b) 2D-HMQC and (c) 2D-COSY analyses.

\subsection{Structural Features of the Target Compound}

The compound crystallized in the NA-space group $C_{c}$ with $Z=4$, and the correct absolute structure was confirmed by the Flack parameter of 0.067(5). Structurally, it consists of a perfectly planar fused triazolo-thiadiazole system, i.e., rings $\mathrm{A}$ and $\mathrm{B}$ attach with the perfectly planar indole moiety (rings $\mathrm{C}$ and D) (Figure 3). The triazolo-thiadiazole and the substituted indole moieties are not coplanar where the angle between the mean plane passing through them is $41.82^{\circ}$.

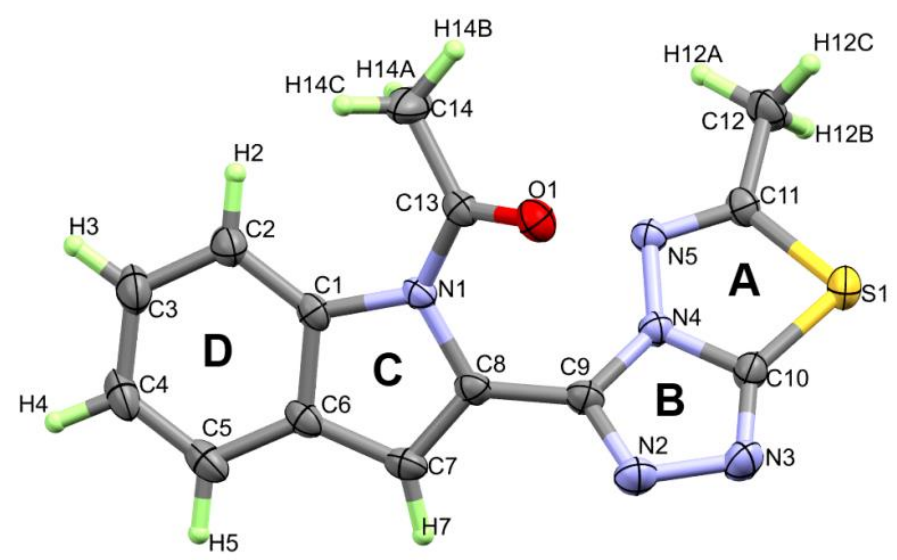

Figure 3. Molecular structure with anisotropic displacement ellipsoids drawn at the $50 \%$ probability level of the target compound. 
Figure 4 illustrates all contacts found in the crystal lattice of title compound (Table 2). The intermolecular hydrogen bonds $\mathrm{C} 5-\mathrm{H} 5 \cdots \mathrm{N} 2$ and $\mathrm{C}-\mathrm{H} 12 \mathrm{~A} \cdots \mathrm{N} 3$ with $\mathrm{H} \cdots \mathrm{N}$ distances of 2.62 and $2.56 \AA$, respectively, as well as C2-H2 ‥ 1 with $2.59 \AA$ link molecules stabilize the crystal packing as depicted in Figure 4. $\mathrm{Cg} \cdots \mathrm{Cg}$ contacts between ring $\mathrm{B}$ and ring $\mathrm{C}$ further enhance the crystal stability with a centroid...centroid distance of $3.769 \AA$, stacking the layers along the $c$ axis.

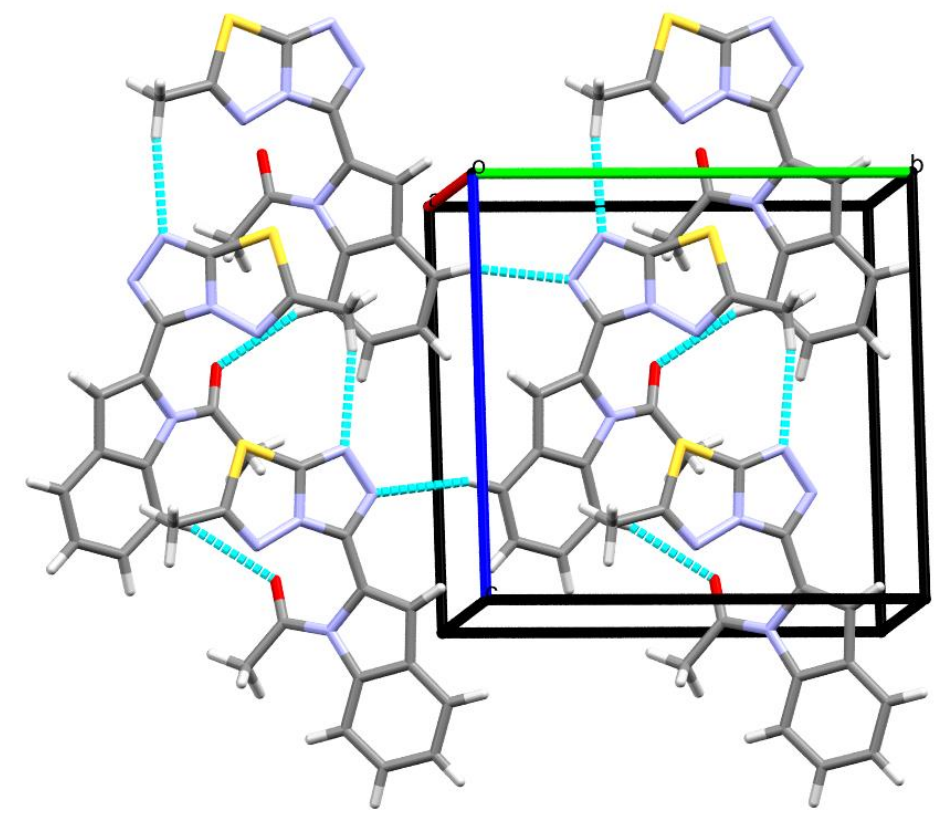

Figure 4. Crystal packing of the target compound.

Table 2. Hydrogen bonding of the target compound.

\begin{tabular}{ccccc}
\hline $\boldsymbol{D}-\mathbf{H} \cdots \boldsymbol{A}$ & $\mathbf{D}-\mathbf{H}$ & $\mathbf{H} \cdots \boldsymbol{A}$ & $\boldsymbol{D} \cdots \boldsymbol{A}$ & $\boldsymbol{D}-\mathbf{H} \cdots \boldsymbol{A}$ \\
\hline $\mathrm{C} 2-\mathrm{H} 2 \cdots \mathrm{O} 1$ (i) & 0.950 & 2.590 & $3.397(3)$ & 142.00 \\
\hline $\mathrm{C} 5-\mathrm{H} 5 \cdots \mathrm{N} 2$ (ii) & 0.950 & 2.620 & $3.522(3)$ & 158.00 \\
\hline C12-H12A $\cdots \mathrm{N} 3$ (i) & 0.980 & 2.560 & $3.528(4)$ & 168.00 \\
\hline \multicolumn{5}{c}{ Symmetry codes: (i) $x,-y+1, z+1 / 2 ;$ (ii) $x,-y, z+1 / 2}$.
\end{tabular}

\subsection{Hirshfeld Analysis of Molecular Packing}

The different contacts in the crystal structure of the target molecule based on a Hirshfeld analysis are shown in Figure 5. The packing of molecules in the crystal is mainly dependent on strong $\mathrm{O} \cdots \mathrm{H}$ and

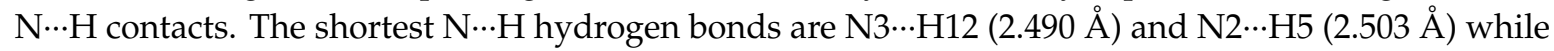
the $\mathrm{O} 1 \cdots \mathrm{H} 2(2.490 \AA)$ is the shortest among the $\mathrm{O} \cdots \mathrm{H}$ contacts based on the Hirshfeld analysis. The $\mathrm{O} \cdots \mathrm{H}$ and $\mathrm{N} \cdots \mathrm{H}$ hydrogen bonding interactions are manifested as spots of red color in the $\mathrm{d}_{\text {norm }}$ and intense spikes in the fingerprint plot (Figure 6). The $\mathrm{O} \cdots \mathrm{H}$ and $\mathrm{N} \cdots \mathrm{H}$ contacts contribute 10.6 and $21.2 \%$ from the overall interactions, respectively. In addition, the $\mathrm{S} \cdots \mathrm{H}, \mathrm{C} \cdots \mathrm{H}$, and $\mathrm{H} \cdots \mathrm{H}$ contacts are weak, as indicated from the blue or white regions and less sharp spikes in the corresponding $d_{\text {norm }}$ maps and fingerprint plots, respectively (Figures S1 and S2, Supplementary data). Their percentage contributions are $7.1,15.1$, and $30.2 \%$, respectively. The rest of the observed contacts have less significance in the molecular packing. 


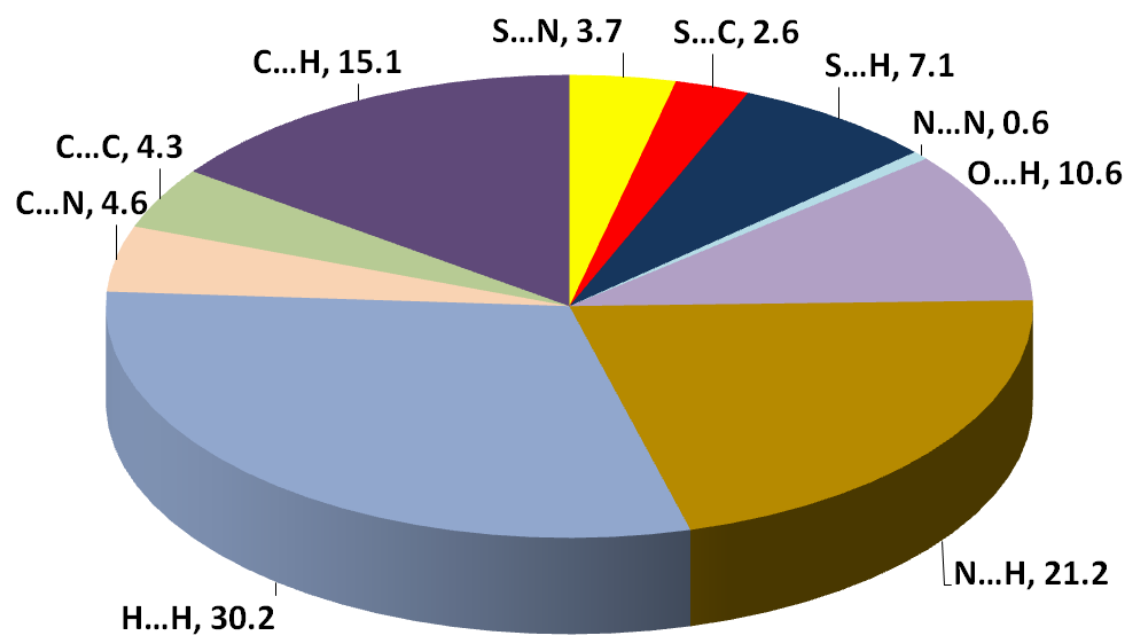

Figure 5. The contacts percentages observed from the Hirshfeld analysis of the target molecule.
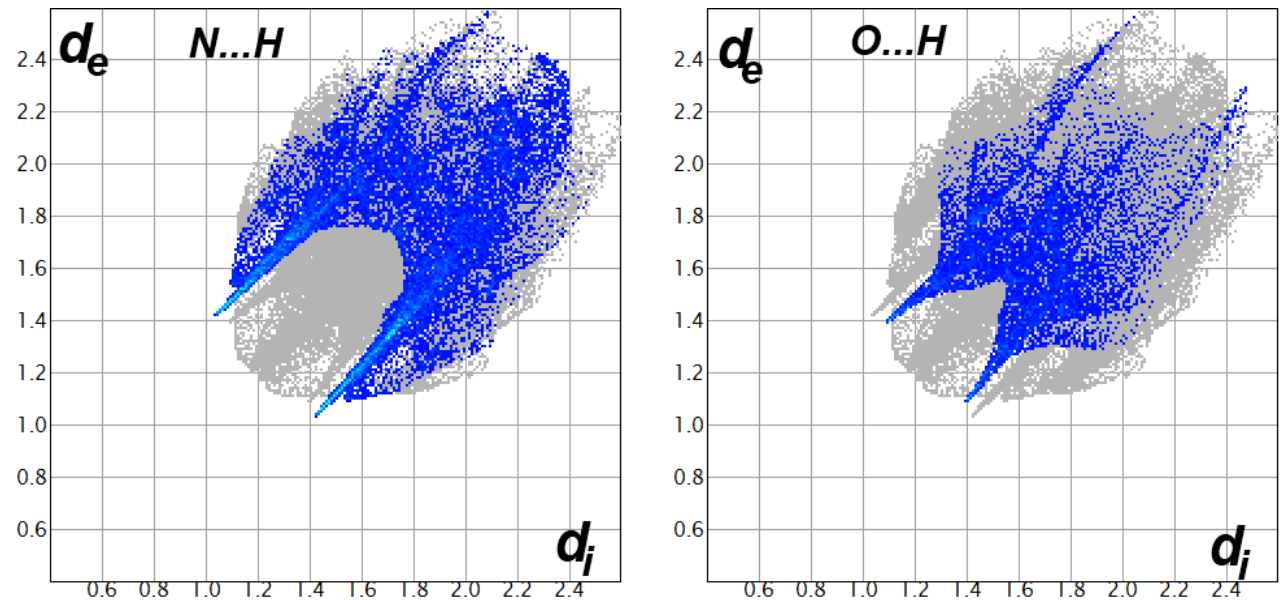

(a)
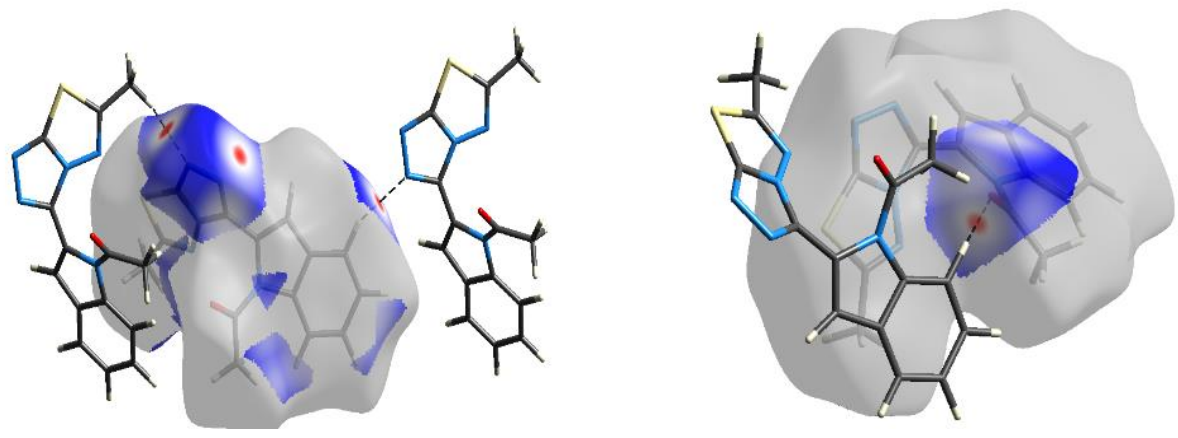

(b)

Figure 6. Fingerprint plot (a) and $d_{\text {norm }}$ surfaces $(\mathbf{b})$ of the $\mathrm{O} \cdots \mathrm{H}$ and $\mathrm{N} \cdots \mathrm{H}$ contacts.

In addition, the shape index map indicated the characteristics of blue/red triangles corresponding

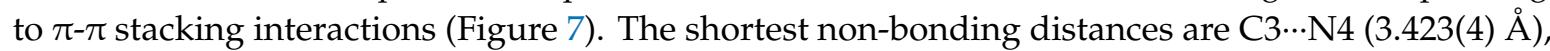

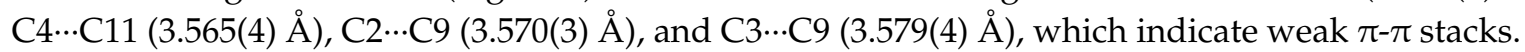




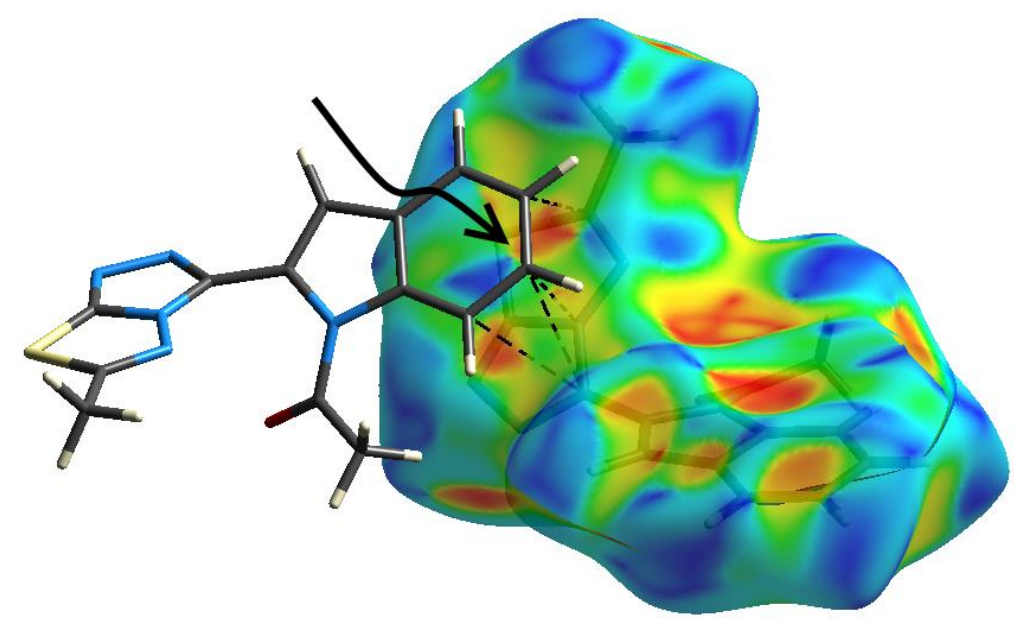

Figure 7. Shape index of the shortest $\pi-\pi$ interactions.

\subsection{DFT Studies}

\subsubsection{Optimized Geometry}

The calculated geometry of the studied molecule matches very well with the X-ray one (Figure 8, Figure S3). Furthermore, the calculated bond distances and angles are in good agreement (Table S1) and correlated very well with the corresponding geometric parameters obtained from the X-ray structure with correlation coefficients of 0.9938 and 0.9915 for bond distances and angles, respectively (Figure 9). The distribution of the natural charges and the molecular electrostatic potential are shown in Figure 10. It is clear that the highest negative charges are related to the nitrogen and oxygen sites, while positive charges are related to the hydrogen and sulphur atoms. As a result of this charge distribution, the calculated dipole moment is 6.6557 Debye. The direction of the dipole moment vector is predicted towards the fused triazole ring (Figure 10). In addition, the red (nitrogen and oxygen sites) and blue (protons) regions in the MEP map indicated the most proper regions as hydrogen bond acceptor and hydrogen bond donor, respectively.

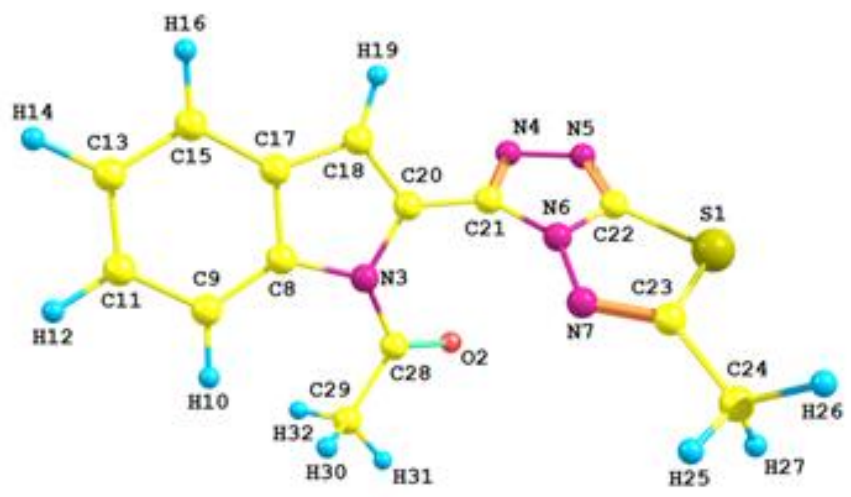

(a)

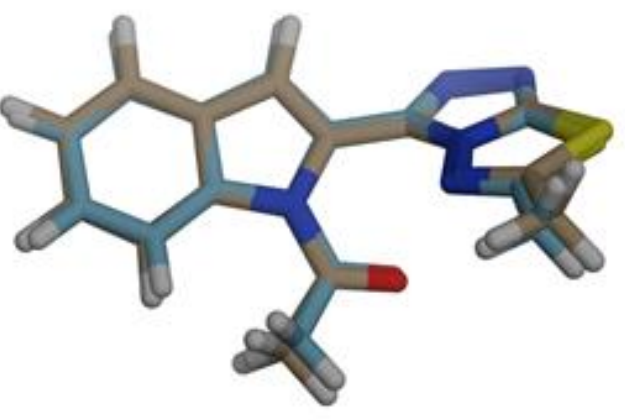

(b)

Figure 8. The optimized geometry (a) and overlay of the optimized geometry with experimental structures (b) for the target compound. Atom numbering refers to Table 3 and is different from that in Figure 3. 
Table 3. The stabilization energies $\mathrm{E}^{(2)}(\mathrm{kcal} / \mathrm{mol})$ and the charge transfer interactions in the target compound ${ }^{\mathrm{a}}$.

\begin{tabular}{|c|c|c|c|c|c|}
\hline Donor NBO & Acceptor NBO & $E^{(2)}$ & $\begin{array}{l}\text { Donor } \\
\text { NBO }\end{array}$ & Acceptor NBO & $E^{(2)}$ \\
\hline$\sigma \rightarrow \sigma^{*}$ & & & $\underline{\mathrm{n} \rightarrow \sigma^{*}}$ & & \\
\hline $\mathrm{BD}(1) \mathrm{S} 1-\mathrm{C} 23$ & $\mathrm{BD}^{*}(1) \mathrm{N} 5-\mathrm{C} 22$ & 6.39 & $\mathrm{LP}(1) \mathrm{O} 2$ & $\mathrm{BD}^{*}(1) \mathrm{N} 3-\mathrm{C} 28$ & 29.33 \\
\hline $\mathrm{BD}(1) \mathrm{N} 4-\mathrm{N} 5$ & $\mathrm{BD}^{*}(1) \mathrm{S} 1-\mathrm{C} 22$ & 9.84 & $\mathrm{LP}(1) \mathrm{O} 2$ & $\mathrm{BD}^{*}(1) \mathrm{C} 28-\mathrm{C} 29$ & 18.88 \\
\hline $\mathrm{BD}(1) \mathrm{N} 4-\mathrm{N} 5$ & $\mathrm{BD}^{*}(1) \mathrm{C} 20-\mathrm{C} 21$ & 5.35 & LP(1)N4 & BD*(1)N5-C22 & 5.30 \\
\hline $\mathrm{BD}(1) \mathrm{N} 4-\mathrm{C} 21$ & $\mathrm{BD}^{*}(1) \mathrm{N} 6-\mathrm{N} 7$ & 5.29 & $\mathrm{LP}(1) \mathrm{N} 4$ & $\mathrm{BD}^{*}(1) \mathrm{N} 6-\mathrm{C} 21$ & 8.43 \\
\hline $\mathrm{BD}(1) \mathrm{N} 6-\mathrm{C} 22$ & $\mathrm{BD}^{*}(1) \mathrm{C} 20-\mathrm{C} 21$ & 4.89 & LP(1)N5 & $\mathrm{BD}^{*}(1) \mathrm{N} 4-\mathrm{C} 21$ & 5.69 \\
\hline $\mathrm{BD}(1) \mathrm{N} 7-\mathrm{C} 23$ & $\mathrm{BD}^{*}(1) \mathrm{N} 6-\mathrm{C} 21$ & 4.93 & LP(1)N5 & $\mathrm{BD}^{*}(1) \mathrm{N} 6-\mathrm{C} 22$ & 8.73 \\
\hline BD(1)C9-C11 & $\mathrm{BD}^{*}(1) \mathrm{N} 3-\mathrm{C} 8$ & 6.82 & LP(1)N7 & $\mathrm{BD}^{*}(1) \mathrm{S} 1-\mathrm{C} 23$ & 14.68 \\
\hline $\mathrm{BD}(1) \mathrm{C} 17-\mathrm{C} 18$ & $\mathrm{BD}^{*}(1) \mathrm{C} 20-\mathrm{C} 21$ & 5.81 & LP(1)N7 & $\mathrm{BD}^{*}(1) \mathrm{N} 6-\mathrm{C} 22$ & 7.94 \\
\hline $\mathrm{BD}(1) \mathrm{C} 18-\mathrm{C} 20$ & $\mathrm{BD}^{*}(1) \mathrm{C} 15-\mathrm{C} 17$ & 4.90 & & & \\
\hline$\pi \rightarrow \pi^{*}$ & & & $\mathrm{n} \rightarrow \pi^{*}$ & & \\
\hline $\mathrm{BD}(2) \mathrm{N} 4-\mathrm{C} 21$ & $\mathrm{BD}^{*}(2) \mathrm{N} 5-\mathrm{C} 22$ & 12.82 & $\mathrm{LP}(2) \mathrm{S} 1$ & $\mathrm{BD}^{*}(2) \mathrm{N} 5-\mathrm{C} 22$ & 26.15 \\
\hline $\mathrm{BD}(2) \mathrm{N} 4-\mathrm{C} 21$ & $\mathrm{BD}^{*}(2) \mathrm{C} 18-\mathrm{C} 20$ & 5.40 & LP(2)S1 & $\mathrm{BD}^{*}(2) \mathrm{N} 7-\mathrm{C} 23$ & 26.45 \\
\hline $\mathrm{BD}(2) \mathrm{N} 5-\mathrm{C} 22$ & $\mathrm{BD}^{*}(2) \mathrm{N} 4-\mathrm{C} 21$ & 13.12 & $\mathrm{LP}(1) \mathrm{N} 3$ & $\mathrm{BD}^{*}(2) \mathrm{O} 2-\mathrm{C} 28$ & 44.97 \\
\hline $\mathrm{BD}(2) \mathrm{C} 8-\mathrm{C} 17$ & $\mathrm{BD}^{*}(2) \mathrm{C} 9-\mathrm{C} 11$ & 19.38 & $\mathrm{LP}(1) \mathrm{N} 3$ & $\mathrm{BD}^{*}(2) \mathrm{C} 8-\mathrm{C} 17$ & 29.26 \\
\hline $\mathrm{BD}(2) \mathrm{C} 8-\mathrm{C} 17$ & $\mathrm{BD}^{*}(2) \mathrm{C} 13-\mathrm{C} 15$ & 18.54 & $\mathrm{LP}(1) \mathrm{N} 3$ & $\mathrm{BD}^{*}(2) \mathrm{C} 18-\mathrm{C} 20$ & 25.74 \\
\hline $\mathrm{BD}(2) \mathrm{C} 8-\mathrm{C} 17$ & $\mathrm{BD}^{*}(2) \mathrm{C} 18-\mathrm{C} 20$ & 16.47 & LP(1)N6 & $\mathrm{BD}^{*}(2) \mathrm{N} 4-\mathrm{C} 21$ & 40.63 \\
\hline $\mathrm{BD}(2) \mathrm{C} 9-\mathrm{C} 11$ & $\mathrm{BD}^{*}(2) \mathrm{C} 8-\mathrm{C} 17$ & 19.34 & LP(1)N6 & BD*(2)N5-C22 & 45.82 \\
\hline $\mathrm{BD}(2) \mathrm{C} 9-\mathrm{C} 11$ & $\mathrm{BD}^{*}(2) \mathrm{C} 13-\mathrm{C} 15$ & 17.83 & LP(1)N6 & $\mathrm{BD}^{*}(2) \mathrm{N} 7-\mathrm{C} 3$ & 27.30 \\
\hline $\mathrm{BD}(2) \mathrm{C} 13-\mathrm{C} 15$ & $\mathrm{BD}^{*}(2) \mathrm{C} 8-\mathrm{C} 17$ & 19.07 & & & \\
\hline $\mathrm{BD}(2) \mathrm{C} 13-\mathrm{C} 15$ & $\mathrm{BD}^{*}(2) \mathrm{C} 9-\mathrm{C} 11$ & 20.65 & & & \\
\hline $\mathrm{BD}(2) \mathrm{C} 18-\mathrm{C} 20$ & $\mathrm{BD}^{*}(2) \mathrm{N} 4-\mathrm{C} 21$ & 9.96 & & & \\
\hline $\mathrm{BD}(2) \mathrm{C} 18-\mathrm{C} 20$ & $\mathrm{BD}^{*}(2) \mathrm{C} 8-\mathrm{C} 17$ & 15.43 & & & \\
\hline
\end{tabular}

a Atom numbering refers to Figure 8.
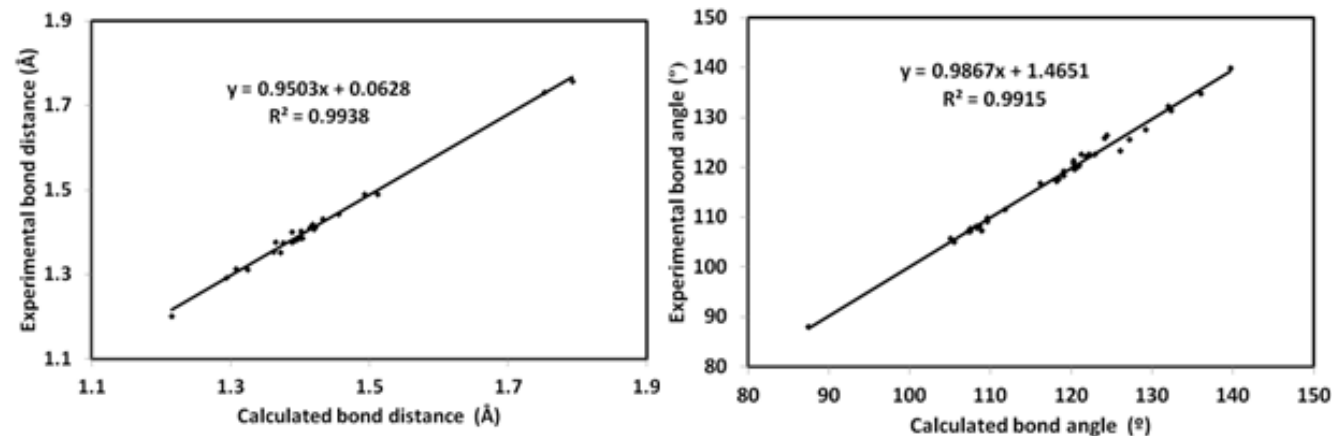

Figure 9. Correlation graphs between the experimental data (bond angles and bond distance) and calculated data.

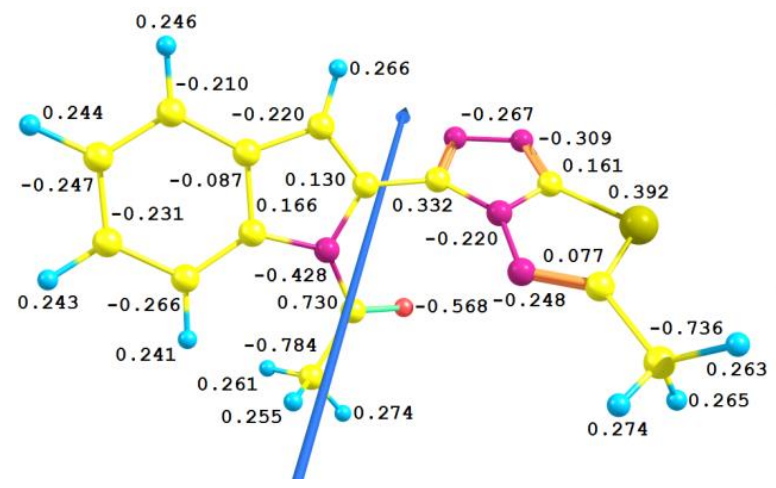

(a)

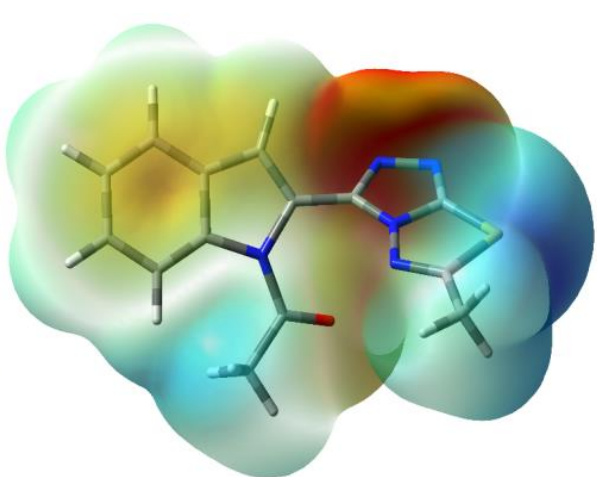

(b)

Figure 10. The natural charges over the optimized structure with dipole moment vector (a) and MEP map (b). 


\subsubsection{Reactivity Studies}

The reactivity indices were calculated using Equations (1)-(5) based on the HOMO and LUMO energies of the studied compound [37-43].

$$
\begin{gathered}
\mathrm{I}=-\mathrm{E}_{\mathrm{HOMO}} \\
\mathrm{A}=-\mathrm{E}_{\mathrm{LUMO}} \\
\eta=(\mathrm{I}-\mathrm{A}) / 2 \\
\mu=-(\mathrm{I}+\mathrm{A}) / 2 \\
\omega=\mu^{2} / 2 \eta
\end{gathered}
$$

The HOMO and LUMO energies were calculated to be -5.8535 and $-1.4346 \mathrm{eV}$, respectively. As a result, the ionization potential (I) and electron affinity (A) were 5.8535 and $1.4346 \mathrm{eV}$, respectively. In addition, the hardness $(\eta=4.4189)$, electrophilicity index $(\omega=1.5025 \mathrm{eV})$, and chemical potential $(\mu=-3.6440 \mathrm{eV})$ were also computed using the frontier molecular orbitals energies. The presented descriptors have strong relation to the chemical reactivity of the compound. In addition, the HOMO is localized over the triazolo-thiadiazole moiety as a starting demand for the intramolecular charge transfer to the LUMO level (Figure 11). The latter is disseminated over the $\pi$-system of the triazole and indole moieties. Hence, the HOMO-LUMO charge transfer is mainly $\pi \rightarrow \pi^{*}$ excitation and the energy of this intramolecular charge transfer is $4.4189 \mathrm{eV}$.

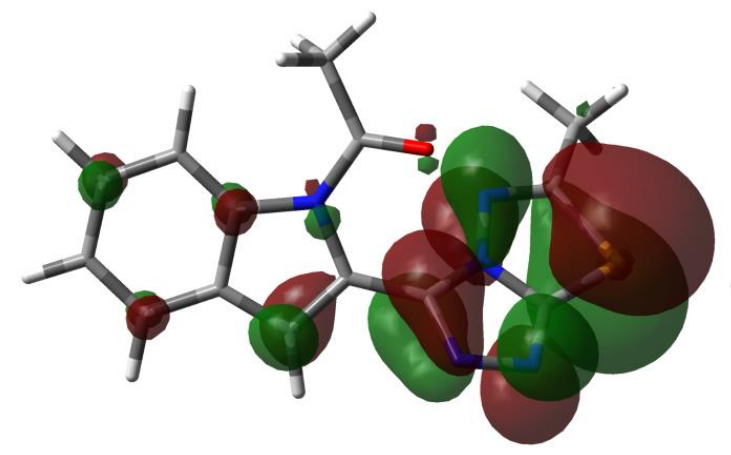

(a)

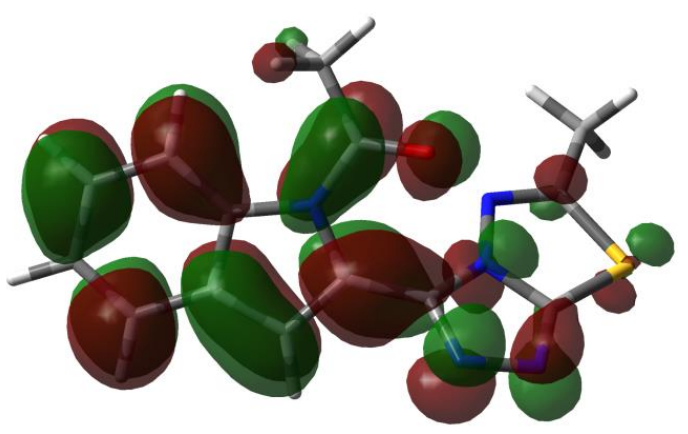

(b)

Figure 11. HOMO (a) and LUMO (b) orbital density of the studied compound.

\subsubsection{NBO Analysis}

The analysis of the different charge transfer interactions within the molecule using second order perturbation theory $[44,45]$ within the framework of the natural bond orbital calculations shed light on the different electron delocalization processes that stabilize the molecular system. The stabilization energies $\left(E^{(2)}\right)$ of the different intramolecular charge transfer interactions within the requisite molecule are listed in Table 3. The system is stabilized by different types of intramolecular charge transfer interactions such as $\sigma \rightarrow \sigma^{*}, \pi \rightarrow \pi^{*}, \mathrm{n} \rightarrow \sigma^{*}$, and $\mathrm{n} \rightarrow \pi^{*}$ electron delocalization processes. The energies of these charge transfer interactions stabilized the studied molecule up to 9.84, 20.65, 29.33, and $45.82 \mathrm{kcal} / \mathrm{mol}$, respectively.

\subsubsection{UV-Vis and NMR Spectra}

The experimental UV-Vis charts were recorded in ethanol and showed absorption bands at $239 \mathrm{~nm}$ in addition to the split band at 293 and $301 \mathrm{~nm}$. In order to assign the origin of these electronic transitions, a TD-DFT calculation was performed by applying the ethanol solvent model. The bands assignment is given in Table 4. The simulated and experimental electronic spectra are assigned in 
Figure 12. The experimentally observed bands were calculated at $245.1 \mathrm{~nm}(\mathrm{f}=0.1208), 283.6 \mathrm{~nm}$ $(\mathrm{f}=0.0674)$, and $307.4 \mathrm{~nm}(\mathrm{f}=0.4712)$, respectively. The complete assignments of the molecular orbitals included in these electronic transitions are presented graphically in Figure 13.

Table 4. The calculated and experimental electronic spectra of the target molecule.

\begin{tabular}{ccccc}
\hline No. & $\left(\boldsymbol{\lambda}_{\text {max }}\right)_{\text {calc }}$ & $\mathbf{f}_{\text {osc }}{ }^{\mathbf{a}}$ & Assignment & $\left(\boldsymbol{\lambda}_{\text {max }}\right)_{\text {observ }}$ \\
\hline I & 307.4 & 0.4712 & HOMO $\rightarrow$ LUMO $(94 \%)$ & 301 \\
II & 283.6 & 0.0674 & H $-1 \rightarrow$ LUMO $(83 \%)$ & 293 \\
III & 245.1 & 0.1208 & $\mathrm{H}-1 \rightarrow \mathrm{L}+1(16 \%), \mathrm{HOMO} \rightarrow \mathrm{L}+2(65 \%)$ & 239 \\
\hline \multicolumn{5}{c}{ a Oscillator strength. }
\end{tabular}

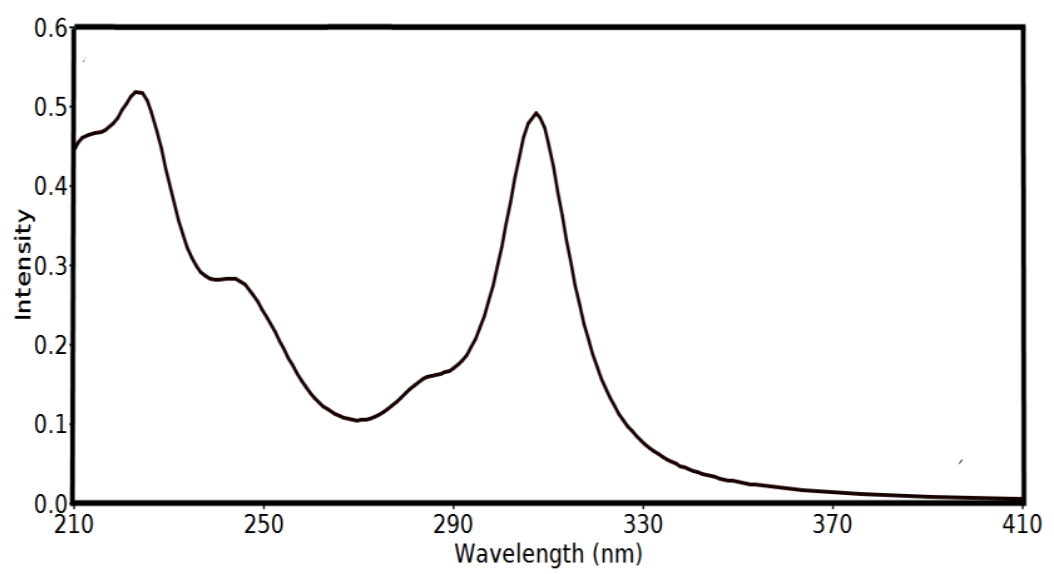

(a)

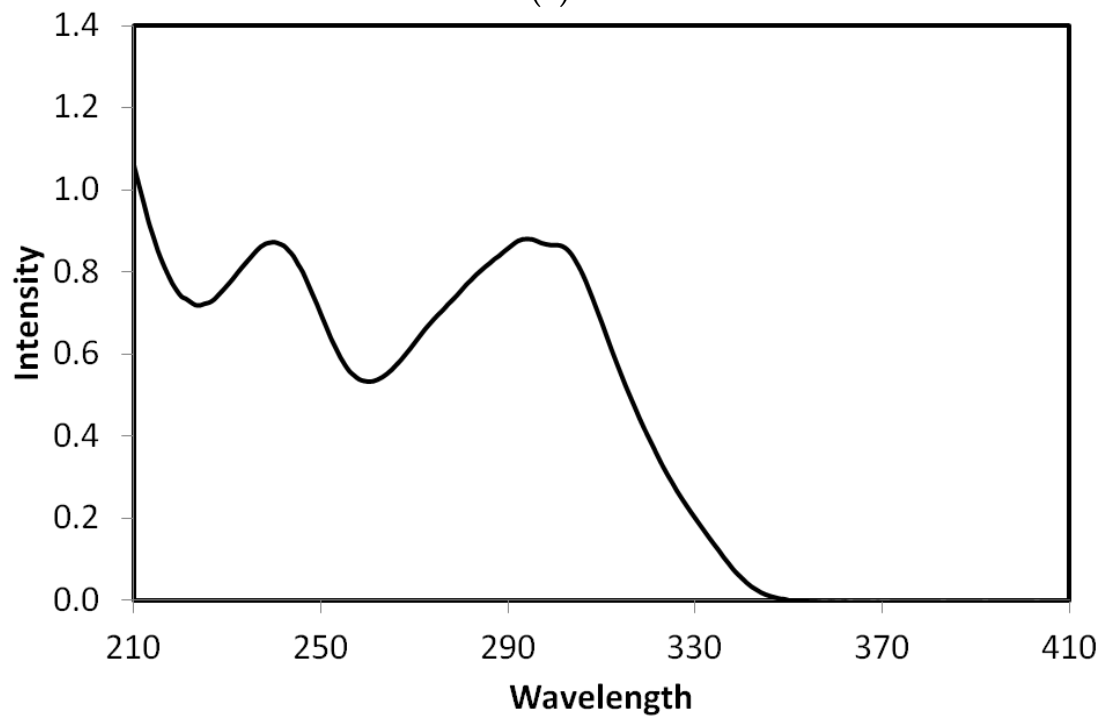

(b)

Figure 12. The correlation UV-Vis chart of the desired molecule via employment of the TD-DFT/B3LYP method (a) and the experimental results (b). 


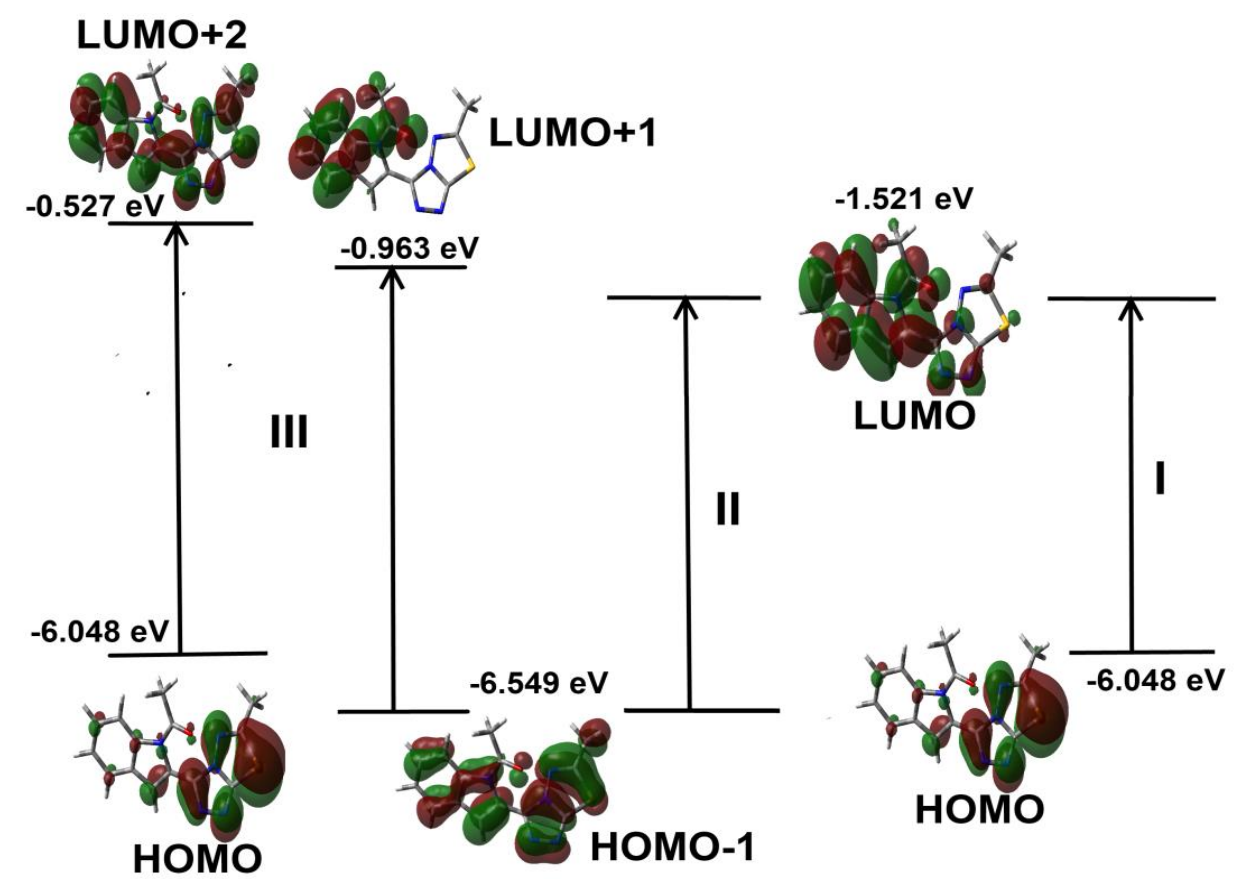

Figure 13. Presentation of the molecular orbitals included in the electronic transitions of the studied compound in ethanol as solvent. The definitions of I, II and III refer to Table 4.

Finally, the chemical shifts (C.S.) of ${ }^{1} \mathrm{H}$ and ${ }^{13} \mathrm{C}$ were computed and the experimental results are listed in the Supplementary data (Table S2). It is clear from Figure 14 that there is a good relation between the calculated and experimental C.S. values. The correlation coefficients are 0.9916 for ${ }^{1} \mathrm{H}-\mathrm{NMR}$ and 0.9971 for ${ }^{13} \mathrm{C}-\mathrm{NMR}$.

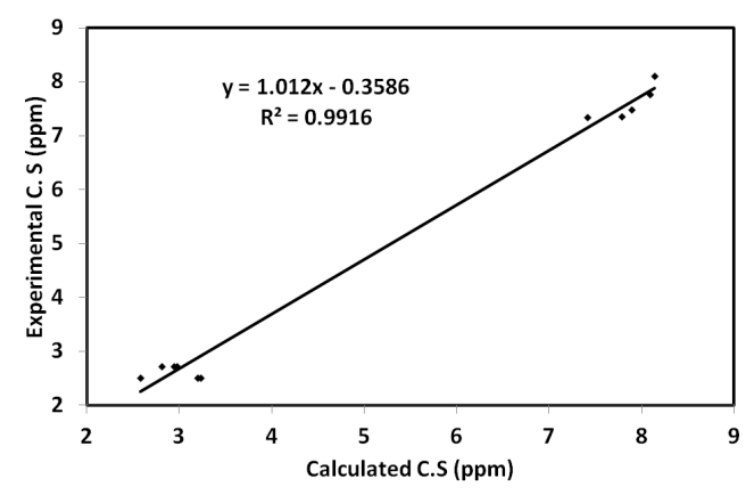

(a)

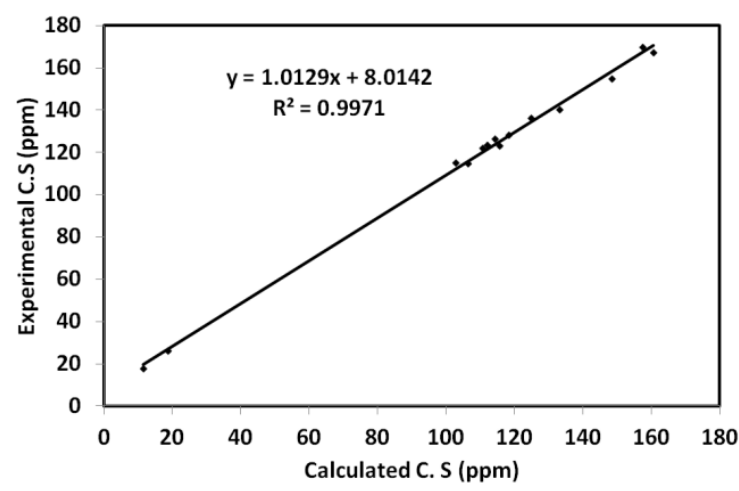

(b)

Figure 14. ${ }^{1} \mathrm{H}-\mathrm{NMR}$ and ${ }^{13} \mathrm{C}-\mathrm{NMR}$ correlation diagram: (a) experimental; (b) calculated.

\section{Conclusions}

We describe a new compound based on an acetylated $N$-indole linked with fused triazolo/thiadiazole motifs. The molecular features and chemical insight of the studied compound are outlined. The supramolecular structure of the desired molecule was analyzed by employing Hirshfeld calculations. In addition, calculated NMR spectra exhibited good harmony with the obtained experimental results. The electronic spectral bands observed experimentally were assigned using TD-DFT calculations. The different electron delocalization processes that stabilize the studied system were analyzed using NBO calculations. In addition, the electronic, and reactivity descriptors were also explored. The utility of the synthesized compound for application will be explored in the near future. 
Supplementary Materials: The following are available online at http://www.mdpi.com/2073-4352/10/7/600/s1. Figure S1: Hirshfeld surfaces of the studied compound; Figure S2: The fingerprint and dnorm of the weak intermolecular contacts in the target compound; Figure S3: Atom numbering of the optimized structure; Table S1 and Table S2: calculated geometric parameters and the calculated and experimental chemical shifts (ppm) of the studied molecule.

Author Contributions: Conceptualization, A.T.A.B. and A.B.; Data curation, S.M.S. and S.Y.; Formal analysis, S.Y. and M.B.; Investigation, A.T.A.B.; Methodology, A.T.A.B.; Software, S.M.S.; Visualization, S.M.S. and A.B.; funding acquisition: A.B. Writing-original draft, A.T.A.B., S.M.S., and A.B. All authors have read and agreed to the published version of the manuscript.

Funding: This research was funded by King Saud University, Researchers Supporting Project Number (RSP-2020/64).

Acknowledgments: The authors would like to extend their sincere appreciation to Researchers Supporting Project Number (RSP-2020/64), King Saud University, Riyadh, Saudi Arabia.

Conflicts of Interest: The authors declare no conflict of interest.

\section{References}

1. Ji, R.V.; Sethi, A.; Nath, M.; Pratap, R. The Chemistry of Heterocycles: Nomenclature and Chemistry of Three to Five Membered Heterocycles; Elsevier: Amsterdam, The Netherlands, 2019.

2. Chen, M.; Lu, S.; Yuan, G.; Yang, S.; Du, X. Synthesis and antibacterial activity of some heterocyclic $\beta$-enamino ester derivatives with 1, 2, 3-triazole. Heterocycl. Commun. 2000, 6, 421-426. [CrossRef]

3. Gujjar, R.; Marwaha, A.; El Mazouni, F.; White, J.; White, K.L.; Creason, S.; Shackleford, D.M.; Baldwin, J.; Charman, W.N.; Buckner, F.S.; et al. Identification of a metabolically stable triazolopyrimidine-based dihydroorotate dehydrogenase inhibitor with antimalarial activity in mice. J. Med. Chem. 2009, 52, 1864-1872. [CrossRef] [PubMed]

4. Huang, M.; Deng, Z.; Tian, J.; Liu, T. Synthesis and biological evaluation of salinomycin triazole analogues as anticancer agents. Eur. J. Med. Chem. 2017, 127, 900-908. [CrossRef] [PubMed]

5. Mohammad, Y.; Fazili, K.M.; Bhat, K.A.; Ara, T. Synthesis and biological evaluation of novel 3-O-tethered triazoles of diosgenin as potent antiproliferative agents. Steroids 2017, 118, 1-8.

6. Ayati, A.; Emami, S.; Foroumadi, A. The importance of triazole scaffold in the development of anticonvulsant agents. Eur. J. Med. Chem. 2016, 109, 380-392. [CrossRef]

7. Akhtar, T.; Hameed, S.; Khan, K.M.; Choudhary, M.I. Syntheses, urease inhibition, and antimicrobial studies of some chiral 3-substituted-4-amino-5-thioxo-1H, 4H-1,2,4-triazoles. Med. Chem. 2008, 4, 539-543. [CrossRef]

8. Timur, İ.; Kocyigit, Ü.M.; Dastan, T.; Sandal, S.; Ceribası, A.O.; Taslimi, P.; Gulcin, İ.; Koparir, M.; Karatepe, M.; Çiftçi, M. In vitro cytotoxic and in vivo antitumoral activities of some aminomethyl derivatives of 2, 4-dihydro-3H-1,2,4-triazole-3-thiones-Evaluation of their acetylcholinesterase and carbonic anhydrase enzymes inhibition profiles. J. Biochem. Mol. Toxic. 2019, 33, e22239. [CrossRef] [PubMed]

9. Sevaille, L.; Gavara, L.; Bebrone, C.; De Luca, F.; Nauton, L.; Achard, M.; Mercuri, P.; Tanfoni, S.; Borgianni, L.; Guyon, C.; et al. 1,2,4-Triazole-3-thione compounds as inhibitors of dizinc metallo- $\beta$-lactamases. ChemMedChem 2017, 12, 972-985. [CrossRef] [PubMed]

10. Baburajeev, C.P.; Mohan, C.D.; Ananda, H.; Rangappa, S.; Fuchs, J.E.; Jagadish, S.; Siveen5, K.S.; Chinnathambi, A.; Ali Alharbi, S.A.; Zayed, M.E.; et al. Development of novel triazolo-thiadiazoles from heterogeneous "green" catalysis as protein tyrosine phosphatase 1B inhibitors. Sci. Rep. 2015, 5, 14195. [CrossRef]

11. Sechi, M.; Derudas, M.; Dallocchio, R.; Dessi, A.; Bacchi, A.; Sannia, L.; Carta, F.; Palomba, M.; Ragab, O.; Chan, C.; et al. Design and synthesis of novel indole $\beta$-diketo acid derivatives as HIV-1 integrase inhibitors. J. Med.Chem. 2014, 47, 5298-5310. [CrossRef]

12. Narayana, B.; Ashalatha, B.V.; Vijayaraj, K.K.; Fernandes, J.; Sarojini, B.K. Synthesis of some new biologically active 1, 3, 4-oxadiazolyl nitroindoles and a modified Fischer indole synthesis of ethyl nitro indole-2-carboxylates. Bioorg. Med. Chem. 2005, 13, 4638-4644. [CrossRef] [PubMed]

13. Mascal, M.; Modes, K.V.; Durmus, A. Concise photochemical synthesis of the antimalarial indole alkaloid decursivine. Angew. Chem. Int. Ed. 2011, 50, 4445-4446. [CrossRef] [PubMed] 
14. Al-Quawasmeh, R.A.; Huesca, M.; Nedunuri, V.; Peralta, R.; Wright, J.; Lee, Y.; Young, A. Potent antimicrobial activity of 3-(4, 5-diaryl-1H-imidazol-2-yl)-1H-indole derivatives against methicillin-resistant Staphylococcus aureus. Bioorg. Med. Chem. Lett. 2010, 20, 3518-3520. [CrossRef]

15. Ty, N.; Dupeyre, G.; Chabot, G.G.; Seguin, J.; Tillequin, F.; Scherman, D.; Michel, S.; Cachet, X. Synthesis and biological evaluation of new disubstituted analogues of 6-methoxy-3- $\left(3^{\prime}, 4^{\prime}, 5^{\prime}\right.$-trimethoxybenzoyl)-1H-indole (BPR0L075), as potential antivascular agents. Bioorg. Med. Chem. 2008, 16, 7494-7503. [CrossRef] [PubMed]

16. Mandour, A.H.; El-Sawy, E.R.; Shaker, K.H.; Mustafa, M.A. Synthesis, anti-inflammatory, analgesic and anticonvulsant activities of 1, 8-dihydro-1-ary1-8-alkyl pyrazolo (3, 4-b) indoles. Acta Pharm. 2010, 60, 73-88. [CrossRef]

17. Islam, M.S.; Barakat, A.; Al-Majid, A.M.; Ali, M.; Yousuf, S.; Choudhary, M.I.; Khalil, R.; Ul-Haq, Z. Catalytic asymmetric synthesis of indole derivatives as novel $\alpha$-glucosidase inhibitors in vitro. Bioorg. Chem. 2018, 79, 350-354. [CrossRef]

18. Bi, W.; Bi, Y.; Xue, P.; Zhang, Y.; Gao, X.; Wang, Z.; Li, M.; Baudy-Floc'h, M.; Ngerebara, N.; Gibson, K.M.; et al. Synthesis and characterization of novel indole derivatives reveal improved therapeutic agents for treatment of ischemia/reperfusion (I/R) injury. J. Med. Chem. 2010, 53, 6763-6767. [CrossRef] [PubMed]

19. Boraei, A.T.; Ghabbour, H.A.; Gomaa, M.S.; El Ashry, E.S.H.; Barakat, A. Synthesis and anti-proliferative assessment of triazolo-thiadiazepine and triazolo-thiadiazine scaffolds. Molecules 2019, 24, 4471. [CrossRef] [PubMed]

20. Boraei, A.T.A.; Gomaa, M.S.; El Sayed, E.S.H.; Duerkop, A. Design, selective alkylation and X-ray crystal structure determination of dihydro-indolyl-1,2,4-triazole-3-thione and its 3-benzylsulfanyl analogue as potent anticancer agents. Eur. J. Med. Chem. 2017, 125, 360-371. [CrossRef]

21. Boraei, A.T.; Ashour, H.K.; El Sayed, H.; Abdelmoaty, N.; El-Falouji, A.I.; Gomaa, M.S. Design and synthesis of new phthalazine-based derivatives as potential EGFR inhibitors for the treatment of hepatocellular carcinoma. Bioorg. Chem. 2019, 85, 293-307. [CrossRef] [PubMed]

22. Boraei, A.T.; Singh, P.K.; Sechi, M.; Satta, S. Discovery of novel functionalized 1, 2, 4-triazoles as PARP-1 inhibitors in breast cancer: Design, synthesis and antitumor activity evaluation. Eur. J. Med. Chem. 2019, 182, 111621. [CrossRef] [PubMed]

23. Boraei, A.T.A.; Sarhan, A.A.M.; Yousuf, S.; Barakat, A. Synthesis of a New Series of Nitrogen/Sulfur Heterocycles by Linking Four Rings: Indole; 1,2,4-Triazole; Pyridazine; and Quinoxaline. Molecules 2020, 25, 450. [CrossRef] [PubMed]

24. Sarhan, A.A.; Boraei, A.T.; Barakat, A.; Nafie, M.S. Discovery of hydrazide-based pyridazino [4, 5-b] indole scaffold as a new phosphoinositide 3-kinase (PI3K) inhibitor for breast cancer therapy. RSC Advances 2020, 10, 19534-19541. [CrossRef]

25. Badria, F.A.; Soliman, S.M.; Atef, S.; Islam, M.S.; Al-Majid, A.M.; Dege, N.; Ghabbour, H.A.; Ali, M.; El-Senduny, F.F.; Barakat, A. Anticancer Indole-Based Chalcones: A Structural and Theoretical Analysis. Molecules 2019, 24, 3728. [CrossRef]

26. Boraei, A.T.; El Ashry, E.S.H.; Barakat, A.; Ghabbour, H.A. Synthesis of new functionalized indoles based on ethyl indol-2-carboxylate. Molecules 2016, 21, 333. [CrossRef]

27. Bruker AXS. SAINT Software reference manual; Bruker AXS: Madison, WI, USA, 1998.

28. Spek, L.A. Single-crystal structure validation with the program PLATON. J. Appl. Chem. 2002, 36, 7-13.

29. Sheldrick, G.M. Crystal structure refinement with SHELXL. Acta Cryst. C. 2015, 71, 3-8. [CrossRef] [PubMed]

30. Macrae, C.F.; Bruno, I.J.; Chisholm, J.A.; Edgington, P.R.; McCabe, P.; Pidcock, E.; Rodriguez-Monge, L.; Taylor, R.; van de Streek, J.; Wood, P.A. Mercury CSD 2.0-new features for the visualization and investigation of crystal structures. J. Appl. Cryst. 2008, 41, 466-470. [CrossRef]

31. Turner, M.J.; McKinnon, J.J.; Wolff, S.K.; Grimwood, D.J.; Spackman, P.R.; Jayatilaka, D.; Spackman, M.A. Crystal Explorer17. 2017. University of Western Australia. Available online: http://hirshfeldsurface.net (accessed on 3 June 2020).

32. Frisch, M.J.; Trucks, G.W.; Schlegel, H.B.; Scuseria, G.E.; Robb, M.A.; Cheeseman, J.R.; Scalmani, G.; Barone, V.; Mennucci, B.; Petersson, G.A.; et al. GAUSSIAN 09, Revision A02 ed; Gaussian Inc.: Wallingford, CT, USA, 2009; GaussView; Version 4.1; Dennington II, R., Keith, T., Millam, J., Eds.; Semichem Inc.: Shawnee Mission, KS, USA, 2007; Available online: https://gaussian.com (accessed on 3 June 2020).

33. Reed, A.E.; Curtiss, L.A.; Weinhold, F. Intermolecular interactions from a natural bond orbital, donor-acceptor viewpoint. Chem. Rev. 1988, 88, 899-926. [CrossRef] 
34. Marten, B.; Kim, K.; Cortis, C.; Friesner, R.A.; Murphy, R.B.; Ringnalda, M.N.; Sitkoff, D.; Honig, B. New Model for Calculation of Solvation Free Energies: Correction of Self-Consistent Reaction Field Continuum Dielectric Theory for Short-Range Hydrogen-Bonding Effects. J. Phys. Chem. 1996, 100, 11775-11788. [CrossRef]

35. Tannor, D.J.; Marten, B.; Murphy, R.; Friesner, R.A.; Sitkoff, D.; Nicholls, A.; Ringnalda, M.; Goddard, W.A.; Honig, B. Accurate first principles calculation of molecular charge distributions and solvation energies from ab initio quantum mechanics and continuum dielectric theory. J. Am. Chem. Soc. 1994, 116, 11875-11882. [CrossRef]

36. Cheeseman, J.R.; Trucks, G.W.; Keith, T.A.; Frisch, M.J. A Comparison of Models for Calculating Nuclear Magnetic Resonance Shielding Tensors. J. Chem. Phys. 1996, 104, 5497-5509. [CrossRef]

37. Foresman, J.B.; Frisch, Æ. Exploring Chemistry with Electronic Structure Methods, 2nd ed.; Gaussian: Pittsburgh, PA, USA, 1996.

38. Chang, R. Chemistry, 7th ed.; McGraw-Hill: New York, NY, USA, 2001.

39. Kosar, B.; Albayrak, C. Spectroscopic investigations and quantum chemical computational study of (E)-4-methoxy-2-[(p-tolylimino) methyl] phenol. Spectrochim. Acta 2011, 78, 160-167. [CrossRef] [PubMed]

40. Koopmans, T.A. Ordering of wave functions and eigenenergies to the individual electrons of an atom. Physica 1933, 1, 104-113. [CrossRef]

41. Parr, R.G.; Yang, W. Density-Functional Theory of Atoms and Molecules; Oxford University Press: New York, NY, USA, 1989.

42. Parr, R.G.; Szentpaly, L.V.; Liu, S. Electrophilicity index. J. Am. Chem. Soc. 1999, 121, 1922-1924. [CrossRef]

43. Singh, R.N.; Kumar, A.; Tiwari, R.K.; Rawat, P.; Gupta, V.P. A combined experimental and quantum chemical (DFT and AIM) study on molecular structure, spectroscopic properties, NBO and multiple interaction analysis in a novel ethyl 4-[2-(carbamoyl) hydrazinylidene]-3, 5-dimethyl-1H-pyrrole-2-carboxylate and its dimer. J. Mol. Strut. 2013, 1035, 427-440. [CrossRef]

44. Hubert, I.J.; Kostova, I.; Ravikumar, C.; Amalanathan, M.; Pinzaru, S.C. Theoretical and vibrational spectral investigation of sodium salt of acenocoumarol. J. Raman Spectrosc. 2009, 40, 1033-1038.

45. Sundaraganesan, N.; Sebastian, S. The spectroscopic (FT-IR, FT-IR gas phase, FT-Raman and UV) and NBO analysis of 4-Hydroxypiperidine by density functional method. Spectrochim. Acta Part A Mol. Biomol. Spectrosc. 2010, 75, 941-952.

(C) 2020 by the authors. Licensee MDPI, Basel, Switzerland. This article is an open access article distributed under the terms and conditions of the Creative Commons Attribution (CC BY) license (http://creativecommons.org/licenses/by/4.0/). 